Saša Redžić

Arheološki institut Beograd

Angelina Raičković

Arheološki institut Beograd

Bebina Milovanović

Arheološki institut Beograd

UDK 904:739.2(497.11)"03"

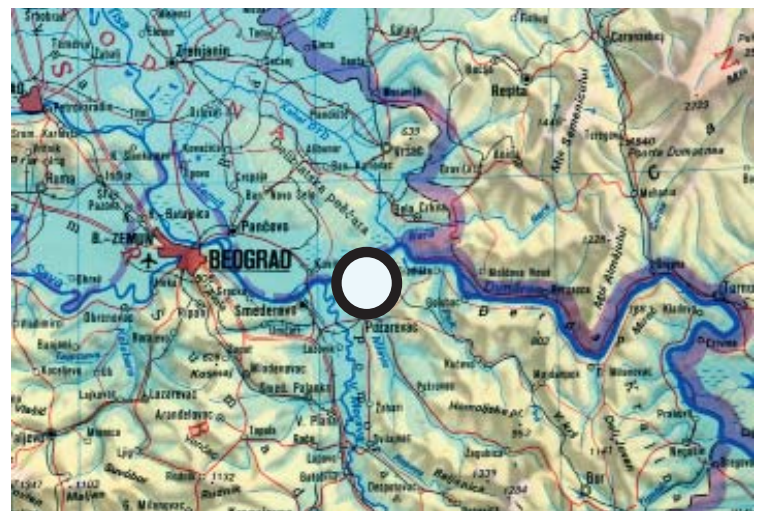

Viminacium, Stari Kostolac, Srbija

LAT 44o 44'09" / LONG 210 12' 42"

\title{
KRSTASTE FIBULE U GROBOVIMA VIMINACIJUMSKIH NEKROPOLA
}

\begin{abstract}
ABSTRAKT
Krstaste fibule sa 79 primeraka, predstavljaju na teritoriji Viminacijuma brojčano najzastupljeniji tip. Od ovog broja čak 58 primeraka je pronađeno unutar grobova neke od viminacijumskih nekropola, što omogućava njihovo precizno vremensko opredeljivanje.

Fibule ovog tipa su izrađivane od bronze, srebra i zlata. Nisu retki ni primerci izrađeni od pozlaćene bronze. Fibule ornamentisane medaljonima sa likom cara i članova njegove porodice kao i natpisima različitog karaktera, do sada nisu nađene na Viminacijumu.

T fibule sa šarnirom predstavljaju obrazac iz koga su se krajem III i početkom IV veka razvile krstaste fibule. Ovaj podatak jasno dokazuje sličnost između najmlađih varijanti T fibula sa šarnirom i najstarijih krstastih fibula.

Krstaste fibule su rasprostranjene na čitavoj teritoriji rimskog carstva, ali su takođe nalažene i na prostorima izvan njegovih granica. Na teritoriji Viminacijuma njihova upotreba se datuje u IV vek.
\end{abstract}

\section{KLJUČNE REČI: KRSTASTE FIBULE, VIMINACIJUM, GROB, NEKROPOLA, DATOVANJE}

Ovde prezentovani tip fibula se u nemačkoj literaturi obično naziva Zwiebelknopffibeln i na lokalitetu Viminacijum je zastupljen sa 79 primeraka, od kojih je 55 ovde prezentovanih pronađeno unutar grobova neke od viminacijumskih nekropola. Do dokumentacije o tri primerka (nađeni su na lokaliteima „Pećine“, „Pirivoj“ i „Brest") koji su nađeni u grobovima nisam uspeo da dođem tako da oni nisu uključeni u rad.

$\mathrm{Na}$ vrhu polukružnog luka se nalazi poprečna greda, na čijim su krajevima dva zadebljanja koja najčešće imaju oblik razvijenih lukovica. Istovetno zadebljanje se nalazi na početku luka. Poprečna greda može imati šestougaoni poprečni presek koji na gornjoj strani često ima plastični dodatak. Kod kasnijih primeraka greda ima oblik trapeza čija je gornja strana profilisana. Lukovice mogu biti okrugle, jajolike, ukrašene facetiranjem ili bez ukrasa. Luk je obično trapezoidnog preseka. Stopa može biti ukrašena facetiranjem, linearnim ili kružnim linijama, volutama, spiralama itd. Čest je slučaj da se istovetan ukras sa luka prenosi i na stopu. 
Igla je sa telom spojena preko šarnira. Držač igle je cevastog oblika. Da bi se sprečilo ispadanje igle iz ležišta, korišćen je mali žičani klin smešten na prelazu luka u stopu ili pločica koja je smeštena u unutrašnjosti držača igle. Istu namenu je imala i pločica koja je jednim svojim krajem bila spojena sa stopom pomoću žičane osovine oko koje je mogla da se rotira kako bi dozvolila zakopčavanje ili otkopčavanje fibule. ${ }^{1} \mathrm{U}$ retkim slučajevima zakopčavanje fibule se izvodilo preko središnje lukovice koja je na svom donjem kraju imala iglu sa navojima. Igla se provlačila kroz otvor u poprečnoj gredi. Ovaj otvor je takođe sadržao navoje pomoću kojih je vršeno fiksiranje igle. Ovakve fibule nisu imale držač igle već im je stopa bila probušena po dužini. $^{2}$

Luksuzni primerci izrađeni od zlata, srebra i pozlaćene bronze mogu biti ornamentisani medaljonima sa likom cara i članova njegove porodice kao i natpisima različitog karaktera. Ovakve fibule su u različitim prilikama od strane cara poklanjane velikodostojnicima, oficirima i činovnicima. Proizvodnja ovakvih fibula je bila u nadležnosti carskog dvora koji je pratio cara na njegovim putovanjima. ${ }^{3}$

Pojas i krstasta fibula pridodata hlamidi, predstavljaju obavezan deo vojne uniforme. Pojas i ova vrsta fibula prihvaćene su i od strane civilnog činovništva koje je vremenom poprimilo vojne odlike. ${ }^{4}$ Pored ovde obrađenih 55 primeraka krstastih fibula, koje su pronađene u 54 groba (dvojni grob G-5428 pronađen na lokalitetu „Pećine“ ima dve fibule, koje u ovom radu imaju redne brojeve 27 i 52), unutar 18 grobova su pronađeni i delovi pojasnih garnitura (pređice, jezičci i aplikacije). Ova činjenica dokazuje gore navedenu konstataciju o zajedničkoj upotrebi pojaseva i ovog tipa fibula, te s tim u vezi ove grobove možemo opredeliti kao grobove vojnika i činovnika. Mastionice pronađene u grobovima zajedno sa fibulama broj 24 i 47 verovatno ukazuju na činovnički stalež pokojnika koji su u njima sahranjeni. Nalazi ovih 1. Saria 1928, 75-77, Abb. 2-5.

2. Bojović 1983, 83, T. LV, 453.

3. Vasić 2001, 196.

4. Vasić 2001, 195. fibula u grobovima žena nisu deo njihove nošnje već pretstavljaju nasleđene predmete. ${ }^{5}$ Sa ovim u vezi treba pomenuti da su od 16 pokojnika (koliko je ukupno polno opredeljenih skeleta od stane antropologa) njih 14 opredeljeni kao muškarci, jedan kao žena i jedan kao dete.

Krstaste fibule bez sumnje vode poreklo od T fibula sa šarnirom. Treba pomenuti da je najmlađa varijanta $T$ fibula sa šarnirom, veoma slična varijanti 1 krstastih fibula. Najznačajnija razlika između ovih tipova je u obliku lukovica koje su kod pomenute varijante (varijanta 6), $T$ fibula sa šarnirom najčešće ovalnog ili bikoničnog oblika ${ }^{6}$ i pretstavljaju prelazni oblik ka lukovicama koje imaju formu zrele glavice luka, a koje su karakteristične za krstaste fibule.

Već pomenuti Sonj (Brigetio) u Mađarskoj predstavlja jedan od centara proizvodnje krstastih fibula, što je potvrđeno nalazom polufabrikata i četvorodelnog kalupa za njihovo livenje. ${ }^{7}$

Krstaste fibule su rasprostranjene na čitavoj teritoriji rimskog carstva kao i na prostorima koji nisu bili njime obuhvaćeni. Nalazi ovih fibula su brojni i na teritoriji Gornje Mezije.

Krstaste fibule se javljaju krajem III veka i nalaze se u upotrebi tokom IV i V veka. Kao najmlađi oblik krstastih fibula Pratel navodi tip Tourne-Apahida koji opredeljuje u svoj tip 7 i datuje u poslednju trećinu $\mathrm{V}$ veka. ${ }^{8}$ Po njemu prelazni oblik ka ovom obliku pretstavljaju fibule tipa Desana-Ten koje se datuju u drugu trećinu V veka. ${ }^{9}$ E. Genčeva smatra na osnovu nalaza najstarijih varijanti krstastih fibula (njen tip 24a, datovan u prvu polovinu III veka i tip $24 \mathrm{~b}$ datovan, u sredinu III veka), da njihov razvoj počinje na teritoriji balkanskog poluostrva. ${ }^{10}$ Ovo mišljenje je svakako pogrešno, jer ove dve varijante njenog tipa 24 treba zbog ovalnog ili bikoničnog oblika

5. Vasić 2001, 196.

6. Redžić 2006, 127-129, T. XXXI/337-338; T.

XXXII/339-344.

7. Keller 1971, 27, Abb. 10.

8. Pröttel 1988, 370, Abb. 8, 6.

9. Pröttel 1988, 370, Abb. 8, 5.

10. Генчева 2004, 62-63, Т. XX, 1-6. 


\begin{tabular}{|c|c|c|c|c|c|c|c|c|c|}
\hline $\begin{array}{c}\text { Položaj } \\
\text { fibule }\end{array}$ & $\begin{array}{c}\text { Dislocirani } \\
\text { skelet }\end{array}$ & Kenotaf & $\begin{array}{c}\text { Desno } \\
\text { rame }\end{array}$ & $\begin{array}{c}\text { Levo } \\
\text { rame }\end{array}$ & Grudi & $\begin{array}{c}\text { Kod } \\
\text { lobanje }\end{array}$ & Karlica & $\begin{array}{c}\text { Leva } \\
\text { podlaktica }\end{array}$ & Noge \\
\hline $\begin{array}{l}\text { Broj } \\
\text { fibula }\end{array}$ & 12 & 1 & 10 & 7 & 4 & 2 & 1 & 1 & 17 \\
\hline
\end{tabular}

Položaj fibula unutar groba

lukovica opredeliti u starije T fibule sa šarnirom.

Uzimajući u obzir do sada nađene krstaste fibule na Viminacijumu, može se reći da ove ne izlaze iz okvira IV veka.

\section{MESTO POLAGANJA FIBULA UNUTAR GROBA I LOKALITETI NA KOJIMA SU NALAŽENE}

Položaj fibula unutar groba je predstavljen u gore priloženoj tabeli.

Od 55 ovde predstavljenih fibula 12 primeraka potiče iz grobova sa dislociranim skeletima tako da njihov položaj nije moguće utvrditi. Jedna fibula je nađena na lokalitetu „Pećine“ u kenotafu broj G-4423.

Uobičajeno mesto na kome su muškarci nosili fibule je desno rame, što je i dokumentovano u 10 slučajeva. Da su krstaste fibule nošene i na levom ramenu svedoči nam i nalaz 7 primeraka iz Viminacijuma.

Nalaze fibula na grudima (4 primerka) i kod lobanje (2 primerka) treba tumačiti njihovaom dislokacijom usled sleganja zemlje. Prvobitno mesto postavljanja ovih fibula je verovatno desno ili levo rame.

Polaganje fibula pored karlice ili preko leve podlaktice možemo tumačiti dvojako. U prvom slučaju moguće je da su fibule zajedno sa spakovanom odećom položene u predelu karlice, a u drugom su fibule možda korišćene za fiksiranje krajeva platna u koje je umotan pokojnik.

U gore priloženoj tabeli možemo videti da predeo nogu predstavlja najčešće mesto polaganja krstastih fibula. Ovakvo pozicioniranje fibule je na Viminacijumu potvrđeno u 17 slučajeva. Stavljanje fibule (zajedno sa odevnim predmetima) pored nogu pokojnika, Burger smatra pokazateljem da se u ovim slučajevima radi o jevrejskom funeralnom kultu. ${ }^{11}$ Autor navodi da se u ovim grobovima koje smatra jevrejskim i čija je orijentacija zapad-istok ili severozapad-jugoistok (u pravcu jerusalimskog hrama, što pretstavlja bitnu karakteristiku jevrejskog funeralnog kulta) po pravilu ne nalazi novac. ${ }^{12}$

Običaj stavljanja fibula pored nogu pokojnika na viminacijumskim nekropolama je zabeležen

11. Burger 1966, 161-162.

12. Burger 1966, 161.

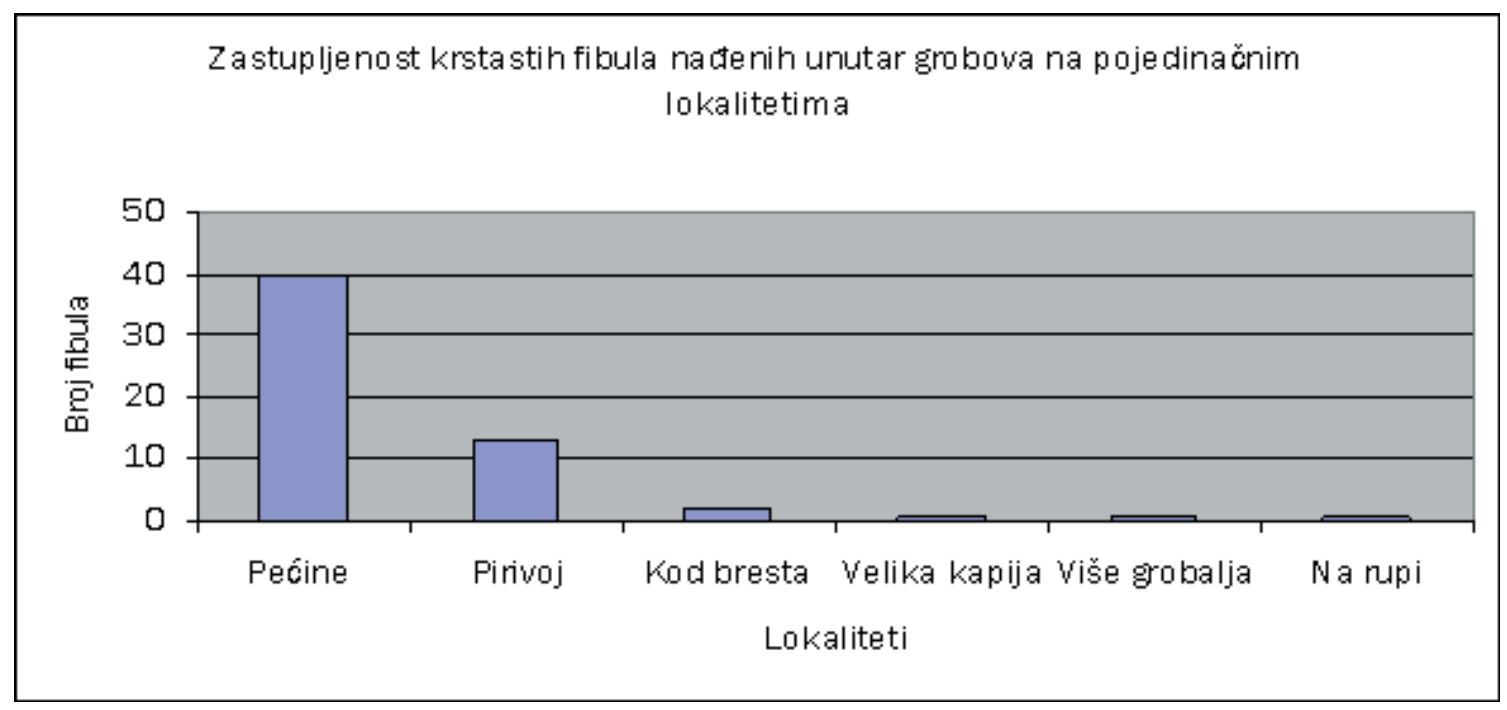


još tokom II i III veka. Pored ovde pomenutih krstastih fibula kod nogu pokojnika je pronađeno još 18 primraka koji se mogu podeliti u 15 tipova. Smatram da fibule stavljene pored nogu pokojnika ne mogu sa sigurnošću da ukažu da se radi o pripadniku jevrejske nacionalnosti, jer je u 9 slučajeva sa fibulama pronađen i novac, a u dva slučaja grobovi su orijentisani istok-zapad, što se kosi sa gore pretstavljenim tvrdnjama Burger. ${ }^{1}$

Brojčani odnos krstastih fibula razvrstanih po lokalitetima na kojima su nađene najbolje se može sagledati na grafikonu sa prethodne strane.

Kao što se može videti na grafikonu, na lokalitetu „Pećine“ nađeno je 40, a na lokalitetu „Pirivoj“ 13 primeraka. Krstaste fibule koje potiču iz grobova na lokalitetu „Kod bresta“ su zastupljene sa dva primerka, dok je na lokalitetima „Velika kapija“, „Više grobalja“ i „Na rupi“ nađen po jedan komad. Ova činjenica jasno ukazuje da se nekropole „Pećine“ i „Pirivoj“ (treba imati u vidu da je na lokalitetu „Pirivoj“ do sada ukupno istraženo 304 groba) i tokom IV veka koriste dosta često, za razliku od ostalih nekropola koje još sredinom III veka gube na značaju. Ovo mišljenje potvrđuje i navod Zotović, da je na teritoriji nekropole „Više grobalja“ tokom IV veka formirano ruralno naselje. ${ }^{2} \mathrm{Na}$ lokalitetu „Pirivoj“ krstaste fibule su nalažene samo u neposrednoj blizini mauzoleja. U istočnom delu ove nekropole, formirane oko komunikacije koja vodi od istočne kapije logora dalje na istok (koja je iskopavanjima i potvrđena), krstaste fibule do sada nisu nađene.

Ova dve nekropole zanimljive su još i zbog izuzetno visokog procenta krstastih fibula nađenih $u$ grobovima u odnosu na fibule iz sloja. Na nekropoli „Pirivoj“ on iznosi 86, dok na nekropoli „Pećine“ čak 90 procenata. Ovaj procenat je kod drugih tipova fibula na Viminacijumu neuporedivo niži. Razlog za ovo verovatno leži u činjenici, da ove dve nekropole krajem IV veka izlaze iz upotrebe, te dakle ne postoje mlađi grobovi koji bi svojim ukopom oštećivali grobove sa krstastim fibulama.

1. Redžić 2006, 161.

2. Zotović, Jordović 1990, 2.

\section{ZAKLJUČAK}

Ovde prezentovane krstaste fibule nađene unutar grobova neke od viminacijumskih nekropola broje 55 primeraka. Ovom broju treba dodati i 3 fibule do čijih podataka nisam uspeo da dođem tako da one nisu uključene u rad.

Fibule ovog tipa su najčešće izrađene od bronze, dok su luksuzni primerci izrađeni od zlata, srebra i pozlaćene bronze. Ovakvi primerci su ornamentisani medaljonima sa likom cara i članova njegove porodice kao i natpisima različitog karaktera. Ove fibule su u različitim prilikama od strane cara poklanjane velikodostojnicima, oficirima i činovnicima. Pojas i krstasta fibula, predstavljaju obavezan deo vojne uniforme, a rado su nošene i od strane civilnog činovništva, što je i dokumentovano prilikom istraživanja viminacijumskih nekropola. Fibule ovog tipa su upotrebljavane prvenstveno od strane muškaraca, ali se mogu naći i u grobovima žena i tada pretstavljaju nasleđene predmete.

Pored desnog i levog ramena, kao mesto gde su krstaste fibule najčešće polagane unutar groba treba pomenuti noge pokojnika. Ovu praksu je Burger tumačila kao pokazatelj da se u tim slučajevima radi o jevrejskom funeralnom kultu, što su opovrgli dokazi otkriveni na nekropolama Viminacijuma.

$\mathrm{Na}$ osnovu brojnosti ovih fibula na lokalitetima „Pećine“ i „Pirivoj“ došao sam do zaključka da su jedino ove dve nekropole (ili bar njihovi delovi) korišćene tokom IV veka.

Krajem III veka krstaste fibule evoluiraju iz T fibula sa šarnirom. Tokom IV veka one se šire po čitavoj teritoriji carstva i ne retko čak prelaze njegove granice. Na teritoriji Viminacijuma njihova upotreba se datuje u IV vek.

\section{Varijanta 1: T. I/1-6}

Fibule ove varijante najčešće imaju poprečnu gredu šestougaonog preseka sa ili bez ukrasa na gornjoj strani. Okrugle ili jajolike lukovice imaju izduženi oblik. Luk trapezoidnog preseka je 
ponekad ukrašen sa gornje strane. Stopa ukrašena linearnim motivima i facetiranjem je obično kraća od luka.

U Gornjoj Meziji ovakve fibule su najčešće skoncentrisane uz Limes. Keler ih opredeljuje u svoj tip 1 (sa podgrupama A i B) i datuje od 290. do 320. godine. ${ }^{3}$ Za razliku od A (naše fibule broj 1-4) podgrupa B ima plastični ukras na gornjoj strani poprečne grede (fibule 5-6). Slično Keleru i Pratel ovu varijantu opredeljuje u svoj tip I koji datuje od 280. do 320. godine. ${ }^{4}$

Ovu varijantu fibula prema obliku lukovica koje još nisu u potpunosti poprimile oblik zrele glavice luka i novcu Licinija I koji je nađen sa primerkom broj 3 treba opredeliti u najstariju fazu koja se na Viminacijumu datuje u početak IV veka.

\section{Varijanta 2: T. II/7-12}

Fibule ove varijante imaju obično facetirane lukovice, mada to ne mora da bude pravilo. Ovu varijantu je Pratel uglavnom opredelio u svoj tip 2 sa varijantama od A do D. Njegova varijanta A nema facetiranu lukovicu, a na stopi ima geometrijske ukrase (naša fibula broj 7). Varijanta B ima facetirane lukovice i može imati linearne ili kružne motive na stopi (naše fibule broj 8-10). Kružni motivi nisu zastupljeni u našoj zbirci. Varijanta D je karakteristična po postojanju «kragne» na prelazu luka u stopu. ${ }^{5}$ Ovakav ornament karakteriše i našu fibulu broj 11 koja ima konične, facetirane lukovice, dok je stopa ornamentisana geometrijskim motivima.

Keler je ovu varijantu opredelio kao svoj tip 2 koji datuje od 310. do 350. godine. ${ }^{6}$

Pratel datuje varijante A i B od 300. do 340. godine, a varijantu $\mathrm{D}$ u drugu trećinu IV veka. ${ }^{7}$ Fibula broj 12 ima facetirane lukovice i na stopi trapezoidne ukrase koje Pratel ne pominje u okviru svog tipa 2, već ga svrstava u tip 3/4 (varijanta D) koji pak nema facetirane lukovice.

3. Keller 1971, 35, Abb. 12.

4. Pröttel 1988, 372, Abb. 11.

5. Pröttel 1988, 353, Abb. 2, 1-4, Abb. 3, 1-6.

6. Keller 1971, 35-36.

7. Pröttel 1988, 357.
Najmlađi novac koji je nađen u grobovima zajedno sa fibulama 7 i 9 iskovan je tokom četvrte decenije IV veka, tako da ovu deceniju, a verovatno i njoj prethodnu treba označiti kao vreme kada je ova varijanta bila u upotrebi.

\section{Varijanta 3:}

T. III/13-18; T. IV/19-22; T. V/23-26; T. VI/27-30; T.VII/31-34; T.VIII/35-38; T. IX/3942; T. X/43-46; T. XI/47-50; T.XII/51;

Fibule ove varijante imaju lukovice koje svojim oblikom podsećaju na glavicu luka. Luk fibule je kraći od stope i često uži od nje. Fibule broj 16, 17, 18, 19, 43 imaju unutar držača igle pločice protiv neželjenog otkopčavanja koja kod primeraka broj 19 i 43 nedostaje, ali je svakako postojala sudeći prema perforaciji na stopi.

Pratel je ovakve fibule opredelio u svoj tip 3/4 koji datuje od druge četvrtine IV veka do početka $\mathrm{V}$ veka koji je prema ukrasu na stopi podelio na četiri varijante (A-D). Njegova varijanta A datovana u drugu četvrtinu IV veka ima na stopi geometrijske ukrase (fibule broj 13-15). Vasić ne isključuje mogućnost da ovaj obilk fibula ne prelazi 340. godinu. ${ }^{8}$ Pratelova varijanta $\mathrm{B}$, datovana u drugu polovinu IV veka, ima na stopi ukrase kružnog oblika (fibule broj 16-40). Ovako ornamentisane fibule se na teritoriji Viminacijuma javljaju početkom četvrte decenije i traju do kraja šeste decenije IV veka. Varijanta C ima na stopi ukrase izvedene volutama (fibule 41-44 od kojih su svi primerci pozlaćeni), dok varijantu D opredeljuju trapezoidni ornamenti (fibule broj 45-49). Autor za varijante C i D ne navodi uža datovanja u okviru tipa, ali smatra da su volute stariji način ukrašavanja iz kojih proističe trapezoidni ornament tipičan za varijantu D. ${ }^{9}$

Keler fibule ove varijante svrstava u svoje tipove 3 (od 340. do 360. godine) i 4 (od 350. do 380. godine). ${ }^{10}$

Vasić smatra, da fibule čija je stopa ornamen-

8. Vasić 2001,191.

.9 Pröttel 1988, 359-364.

10. Keller 1971, 35, Abb. 12. 
tisana volutama $\mathrm{u}$ obliku «pelti» treba izdvojiti u poseban tip koji on datuje od 308. do približno 336/7. godine. ${ }^{1}$ Isti autor navodi bronzanu fibulu sa pozlatom nađenu na lokalitetu «Pećine» u grobu G-1178 zajedno sa novcem iskovanim u vremenskom intervalu od 320. do 329/30. godine. ${ }^{2}$ Obradom ovog novca ustanovljeno je da je iskovan u Arlu 321. godine (RIC 233). Luk i stopa ovog primerka su ukrašeni u Niello tehnici. ${ }^{3}$ Do ovog primerka nisam uspeo da dođem, te stoga on nije uključen u rad.

$\mathrm{Na}$ osnovu novca nađenog zajedno sa fibulama ove varijante, koji je kovan za Konstantina i članove njegove porodice (naše fibule broj 18, 23, $24,33,36,37,39$, 43, kao i gore pomenuta fibula ukrašena u Niello tehnici). Smatram da ove fibule na Viminacijumu treba datovati od početka treće pa do kraja šeste decenije IV veka.

\section{Varijanta 4: T. XII/52-53}

Fibule ove varijante imaju lukovice u obliku glavice luka. Luk fibule je kratak i masivan. Stopa fibule je ukrašena volutama. Oba primerka su izrađena od pozlaćene bronze.

Pratel je ovakve fibule opredelio u svoj tip 5 koji datuje od 350. do 415 . godine. ${ }^{4}$

Keler ovakve fibule pripaja svom tipu 5 datovanom od 370. do 400. godine. ${ }^{5}$

Uzevši u obzir promene nastale na ovim fibulama, koje ih donekle čine različitim od fibula prethodne varijante, ali i nalaz primerka broj 52 unutar istog groba zajedno sa fibulom broj 27 varijante 3, smatram da njihovu upotrebu na teritoriji Viminacijuma treba opredeliti u sredinu IV veka.

\section{Varijanta 5: T. XII/54-55}

Sve fibule ove varijante su izrađene od pozlaćene bronze i imaju facetirane lukovice. Luk im je kao i kod prethodne varijante kratak i masivan. Ažurirana stopa fibule je ukrašena volutama.

1. Vasić 2001, 195.

2. Vasić $2001,185$.

3. Spasić-Đurić 2002, 96-98, sl. 79.

4. Pröttel 1988, 364-369.

5. Keller 1971, 35, Abb. 12.
Pratel je slične fibule uvrstio u svoj tip 6 koji hronološki opredeljuje od 390. do 460. godine. ${ }^{6}$

Keler fibule ove varijante svrstava u svoje tipove 6 koje datuje u prvu polovinu $\mathrm{V}$ veka. ${ }^{7}$

Fibule ove varijante na Viminacijumu treba datovati u drugu polovinu IV veka.

\section{RESUME \\ Cross-like Fibulae in Graves of the Viminacium Cemetery}

In this paper 55 examples of cross-like fibulae are presented, which were found in graves of some of the necropoles at Viminacium. Another three examples of such fibulae should be added to this number, although due to incapability to gain access to them the author did not include them in this paper.

Fibulae of this type are mostly made of bronze, while some of the luxurious examples were made of gold, silver and silver coated bronze. Such examples are decorated with medallions bearing images of emperors and members of their families, as well as with various inscriptions. On different occasions, such fibulae were donated as presents to dignitaries, military officers and officials.

A belt and a cross-like fibula present an obligatory part of military uniforms, although they were also worn by civilians, which was documented while investigating the Viminacium necropoles. They were mostly worn by men, but they can sometimes be found in female graves, when they represent inherited objects.

Beside left and right shoulder, where such fibulae were mostly found within graves, they were also found beside feet. Burger considered this practice as Jewish funerary cult, but this was denied by the Viminacium finds.

According the number of the fibulae found at the sites „Pećine“ and „Pirivoj" the author was able to conclude that these necropoles, or at least

6. Pröttel 1988, 369-372.

7. Keller 1971, 52. 
some parts of them, were frequently in use during $4^{\text {th }}$ century.

At the end of $3^{\text {rd }}$ century the cross-like fibulae derive from the " $T$ " shaped fibulae with hinge. During $4^{\text {th }}$ century they were spread throughout the Roman empire, sometimes even outside its borders. At the territory of Viminacium they are dated into $4^{\text {th }}$ century.

Translated by M. Tapavički-Ilić

\section{BIBLIOGRAFIJA}

\section{Bojović 1983}

D. Bojović, Rimske fibule Singidunuma, Beograd 1983.

\section{Burger 1966}

A. S. Burger, The late Roman Cemetery at Sárgvár, Acta archaeologica academiae scientiarum hungaricae 18, Budapest 1966.

\section{Генчева 2004}

Е. Генчева, Римските фибули от Бьлгария, Велико Тьрново 2004.

\section{Keller 1971}

Die spätrömischen Grabfunde in Südbayern, Münchner Beiträge zur Vor- und Frühgeschichte, Band 14, München 1971.

\section{Pröttel 1988}

P. M. Pröttel, Zur Chronologie der Zwiebelknopffibeln, Jahrbuch des Römischen-Germanischen Zentralmuseums Mainz, 35. Jahrgang, Teil 1, Mainz 1988, 347-372.

\section{Redžič 2006}

S. Redžić, Nalazi rimskih fibula na nekropolama Viminacijuma, magistarska teza u rukopisu, Beograd 2006.

\section{Saria 1928}

B. Saria, Fibeln mit Sperrvorrichtung, Vjesnik hrvatskog arheološkog društva, sveska XV, Zagreb 1928 , 73-80.

\section{Spasić-Đurić 2002}

D. Spasić-Đurić, Viminacijum glavni grad rimske provincije Gornje Mezije, Požarevac 2002.

\section{Vasić 2001}

M. Vasić, Osvrt na nalaz IV veka iz Starčeva, Zbornik Narodnog muzeja, broj XVII-1, Beograd 2001, 175-201.

\section{Zotović, Jordović 1990}

Lj. Zotović, Č. Jordović, Nekropola „,Više Grobalja“, Viminacium I, Beograd 1990. 
T. I
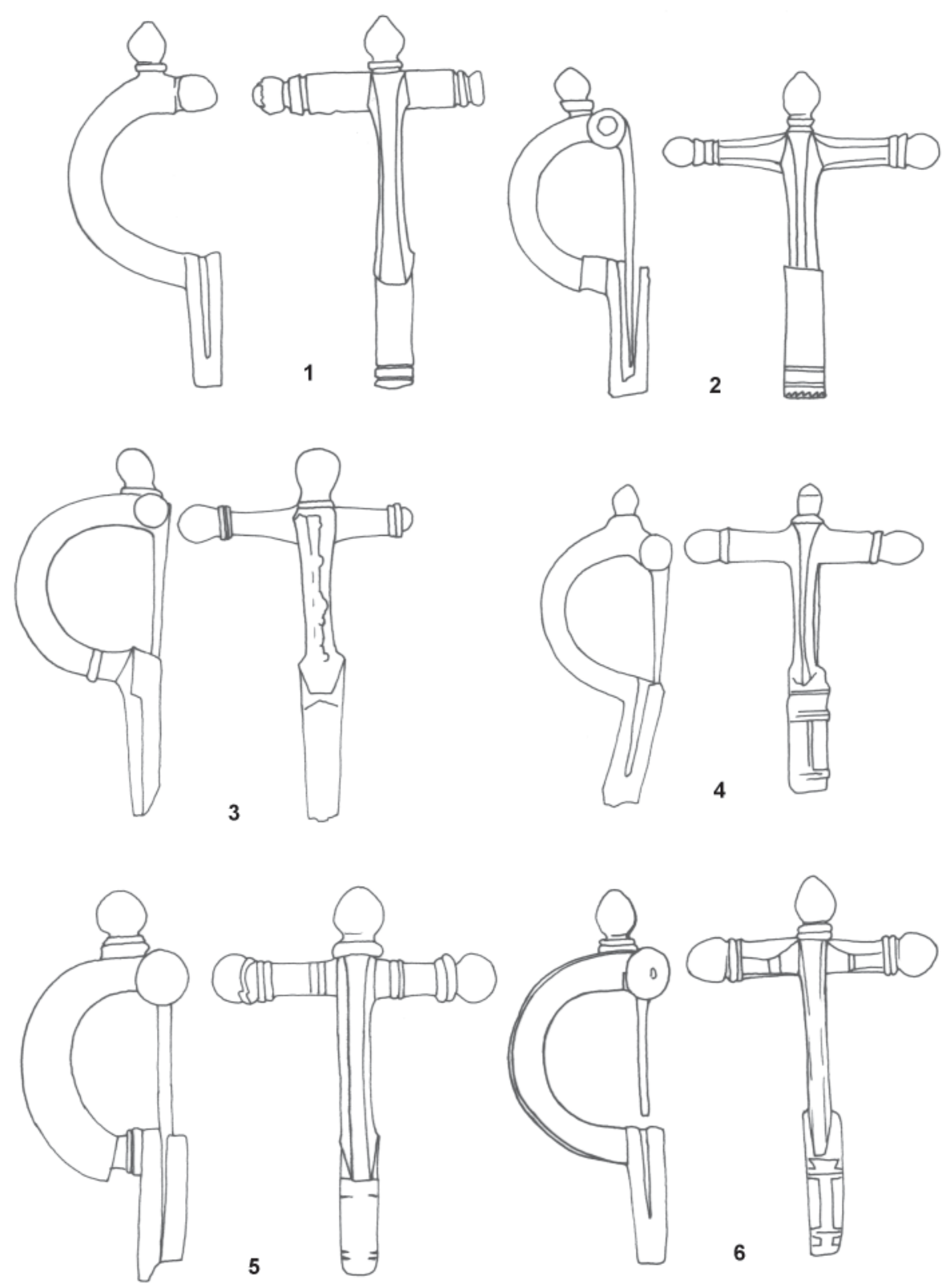

R 2:3 
T. II
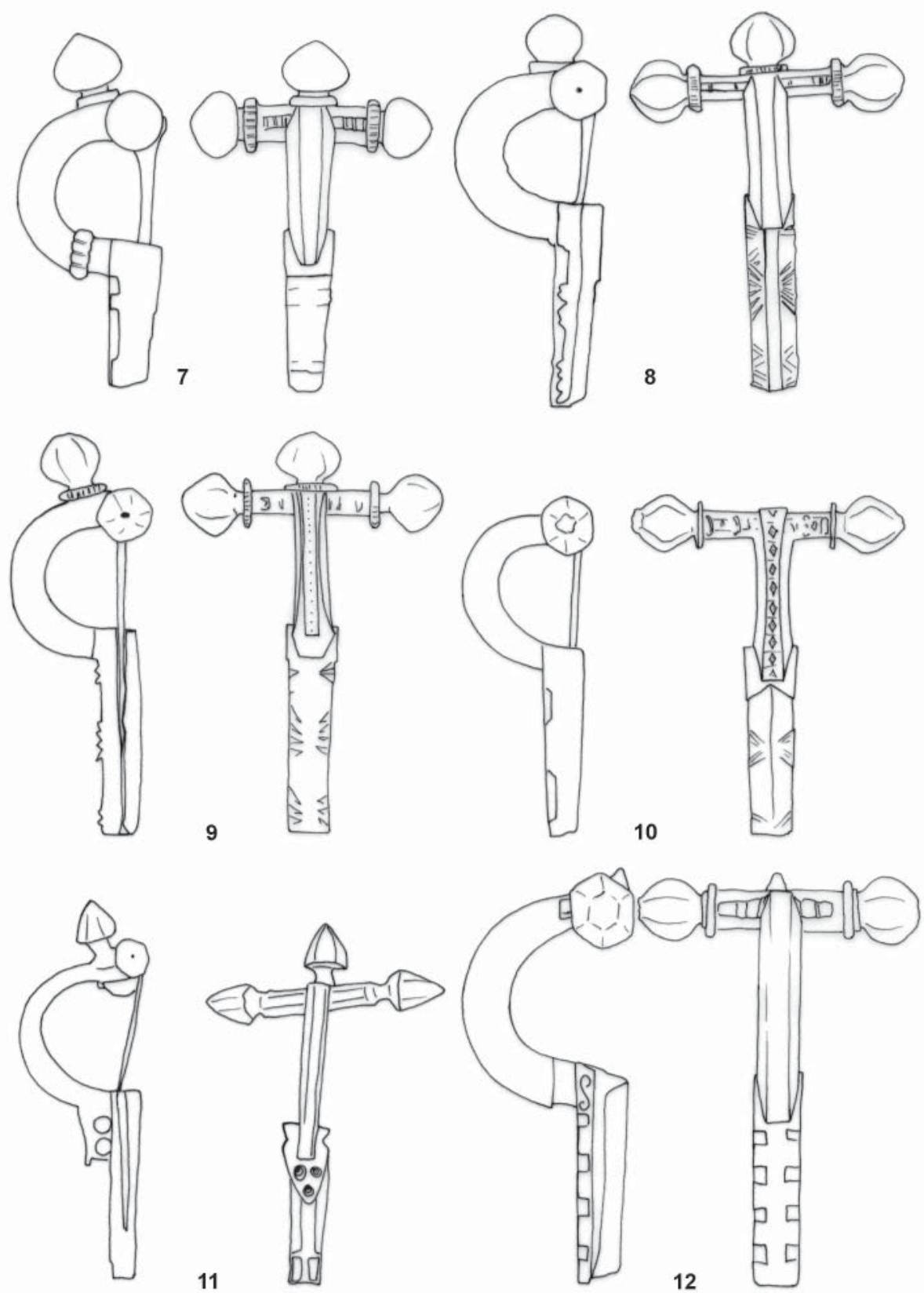

R 2:3 
T. III
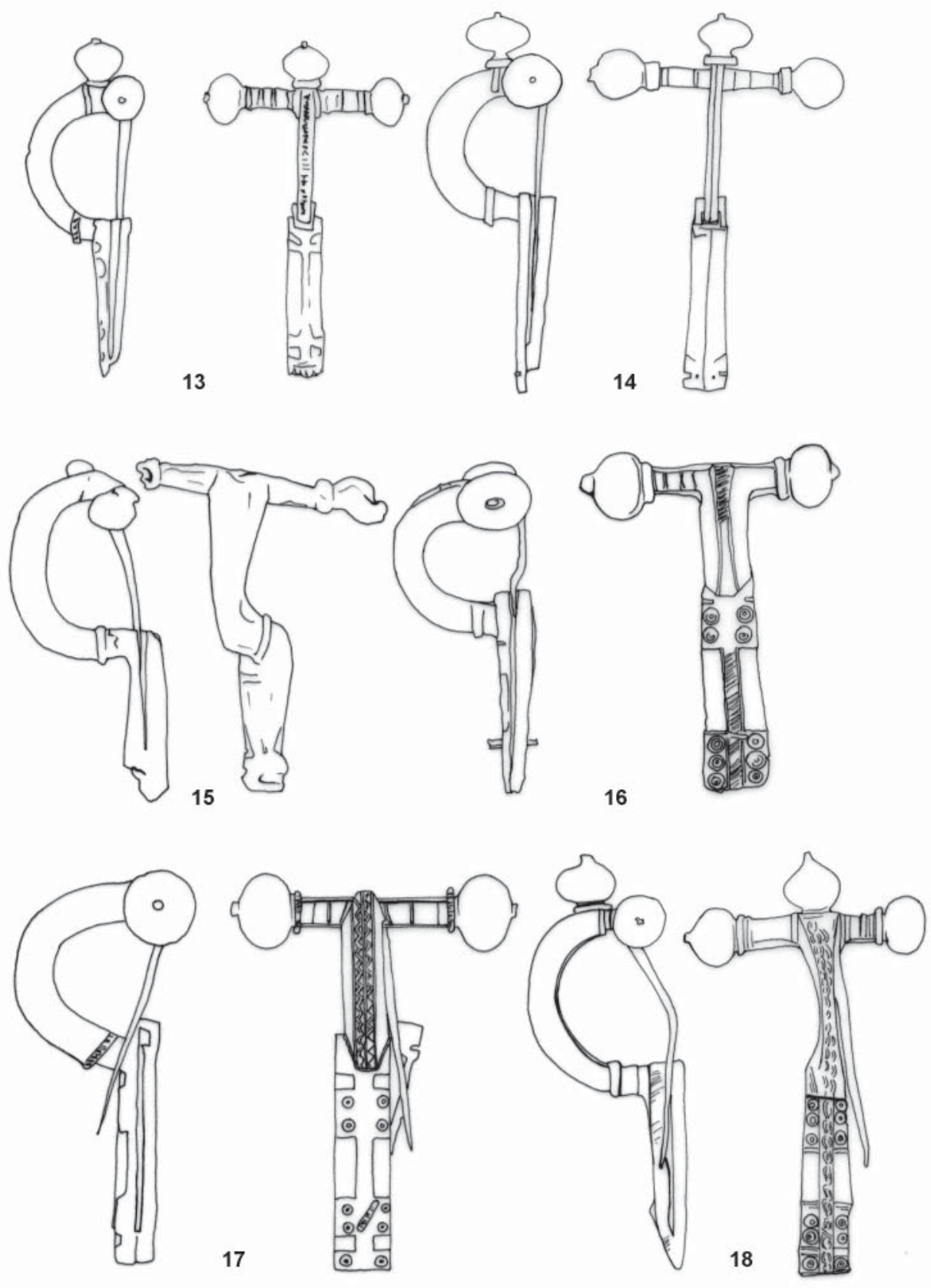

R 2:3 
T. IV
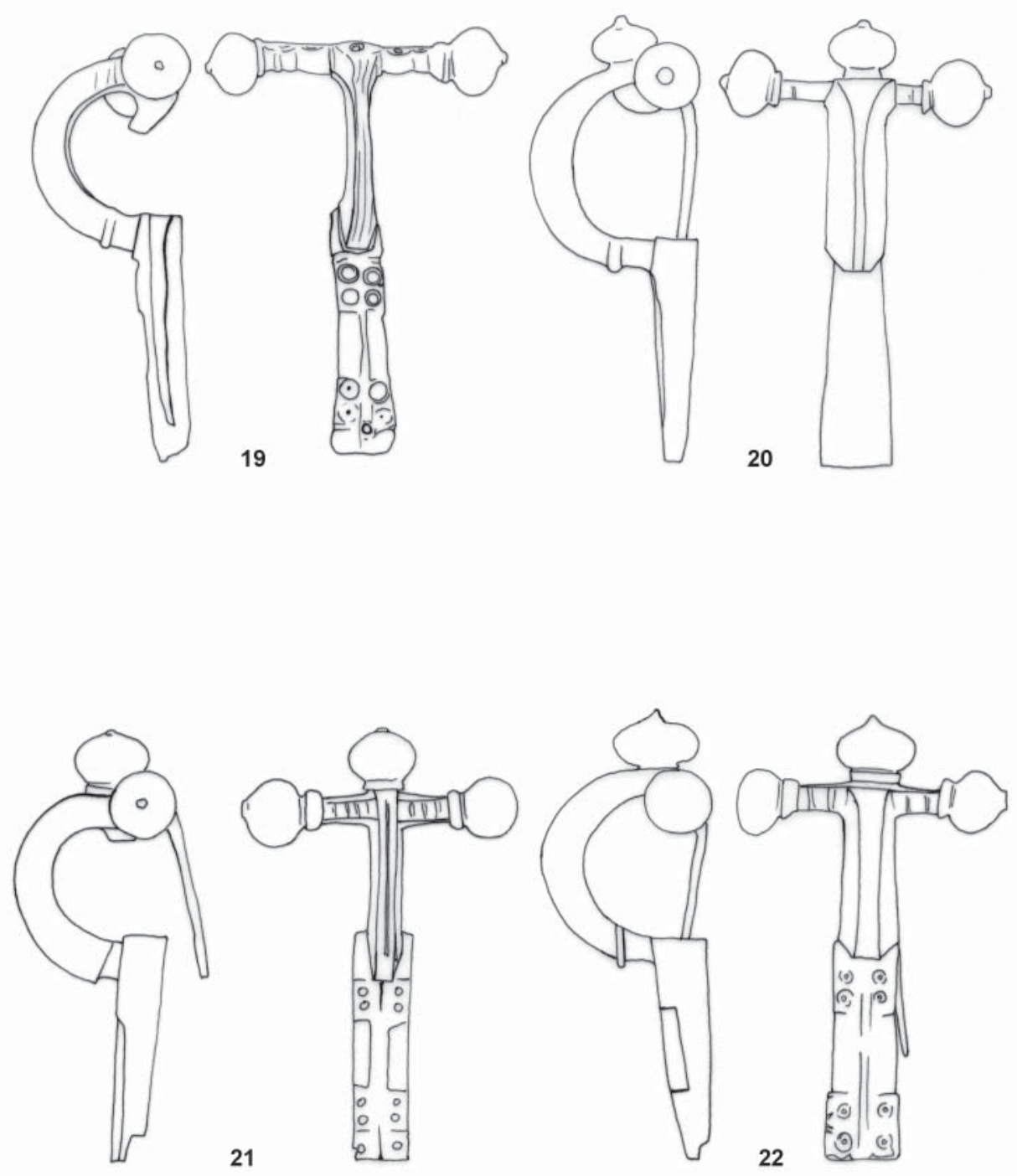

R 2:3 
T. V
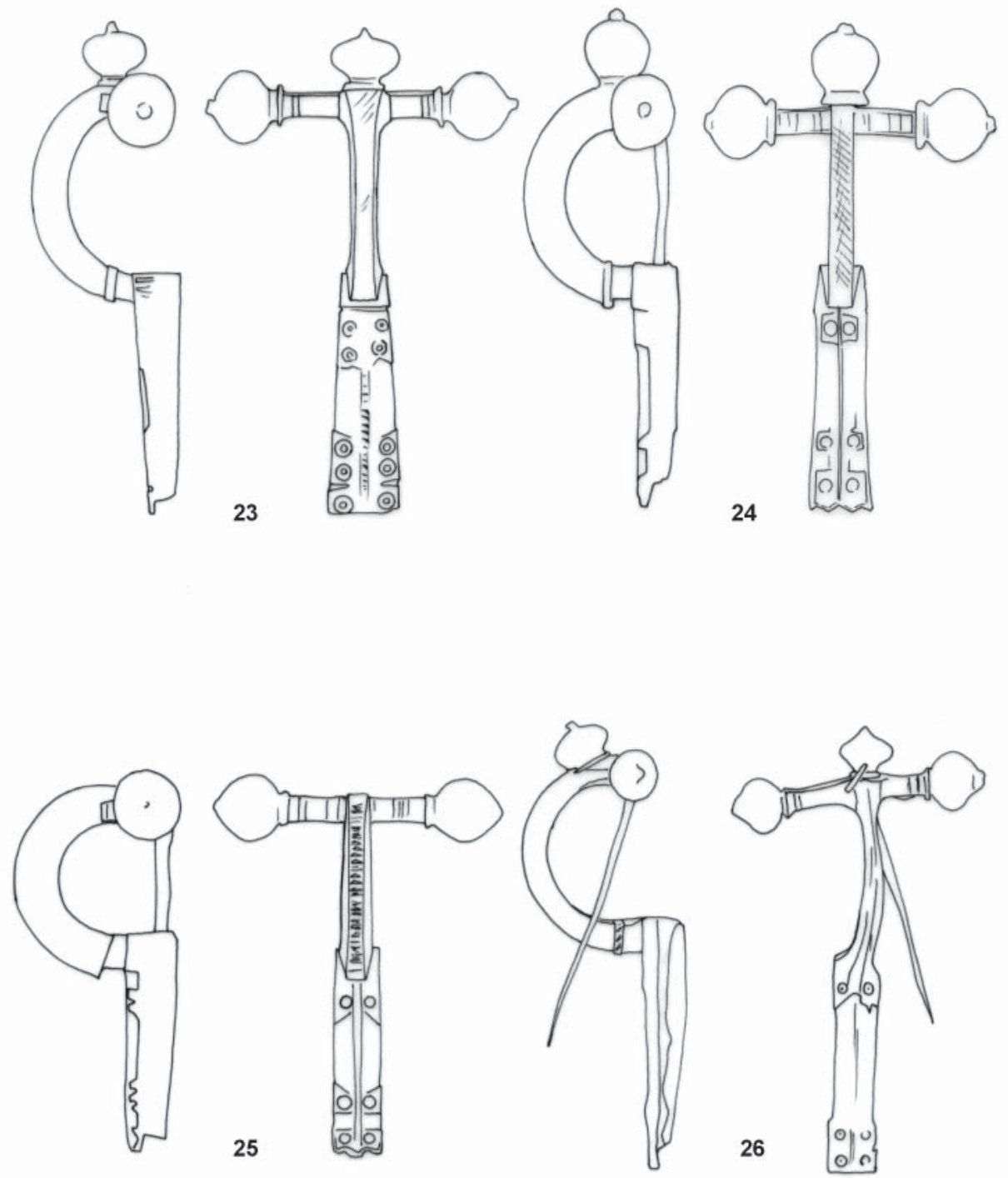

R 2:3 
T. VI
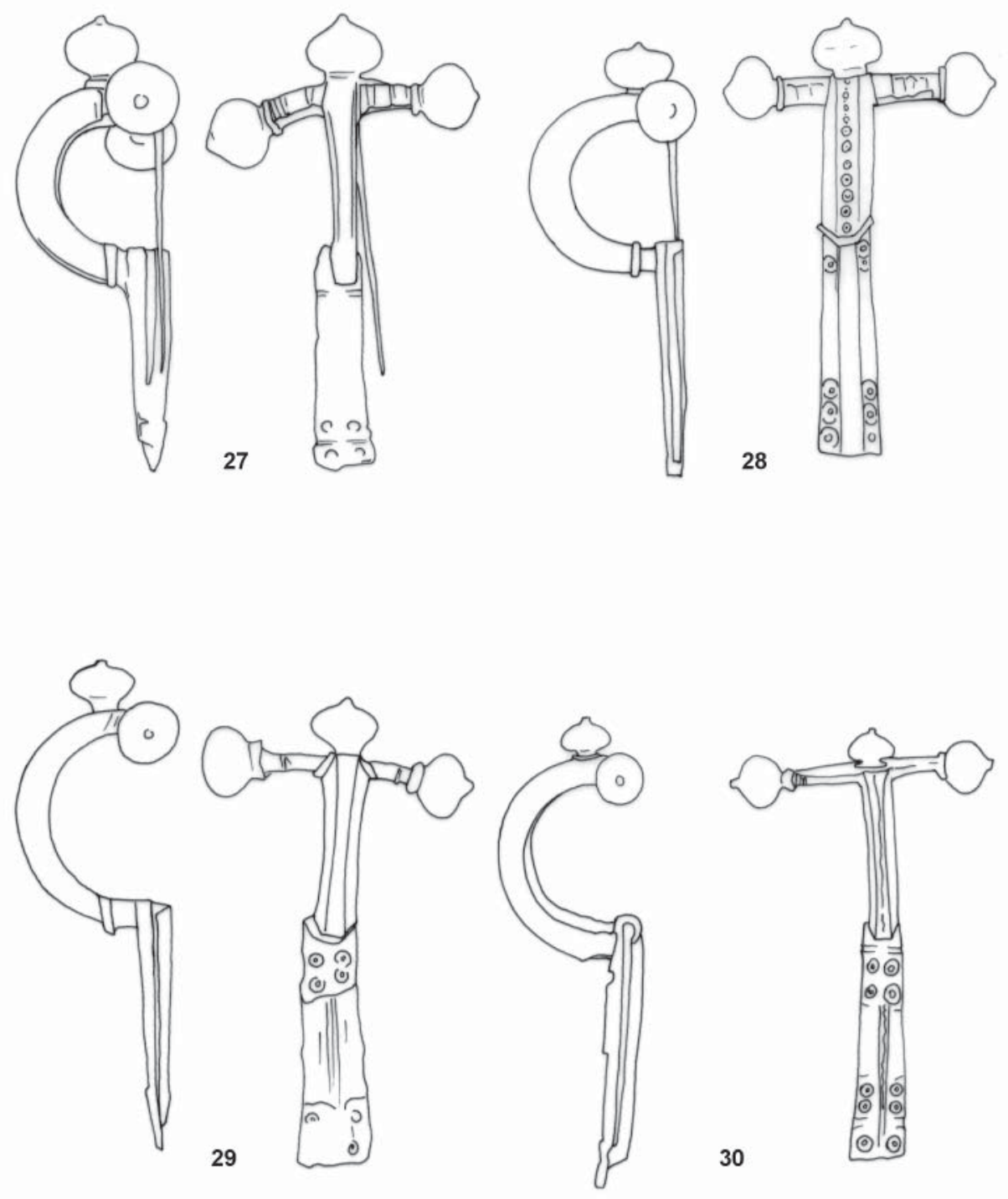

R 2:3 
T. VII
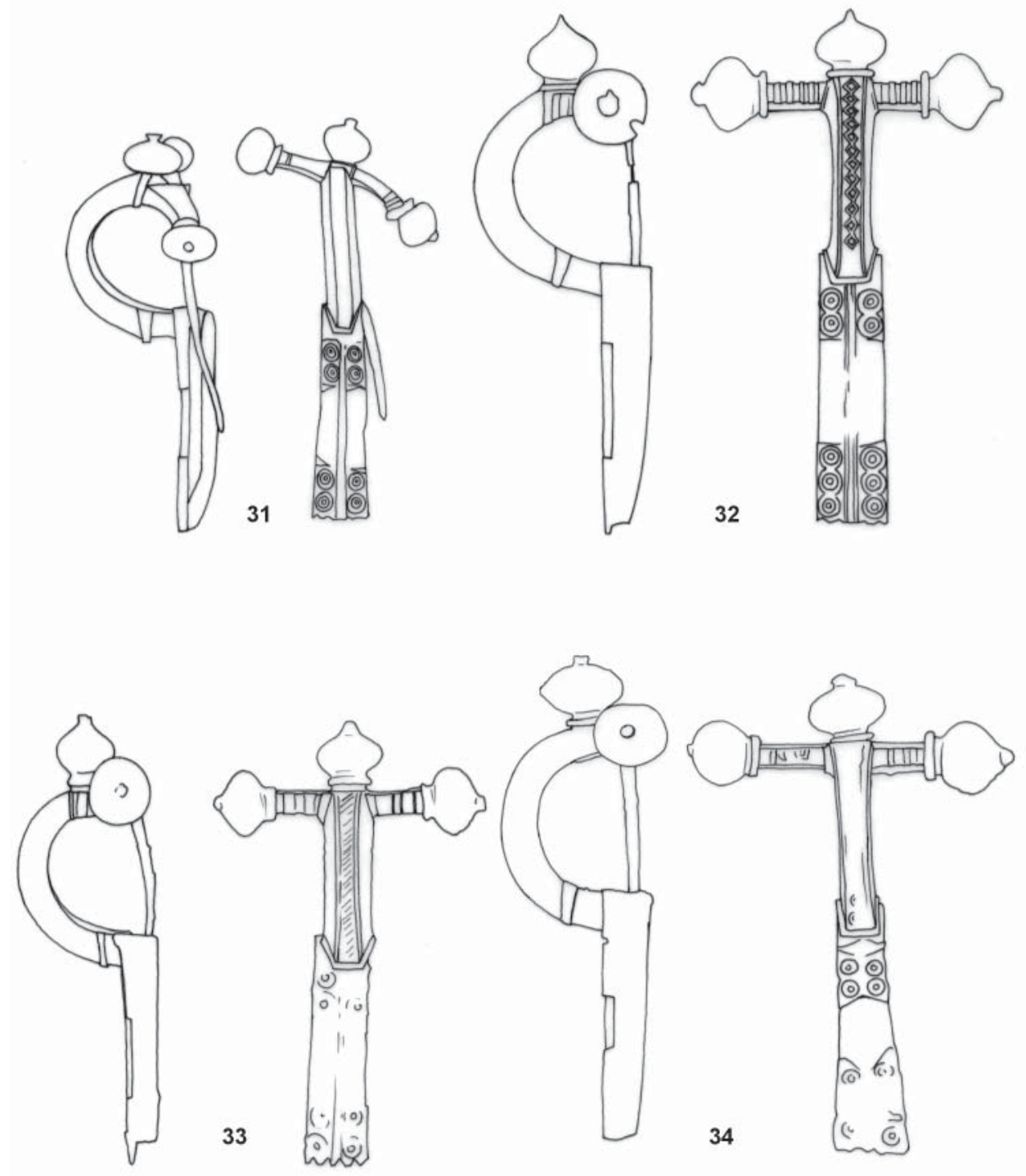

R 2:3 
T. VIII
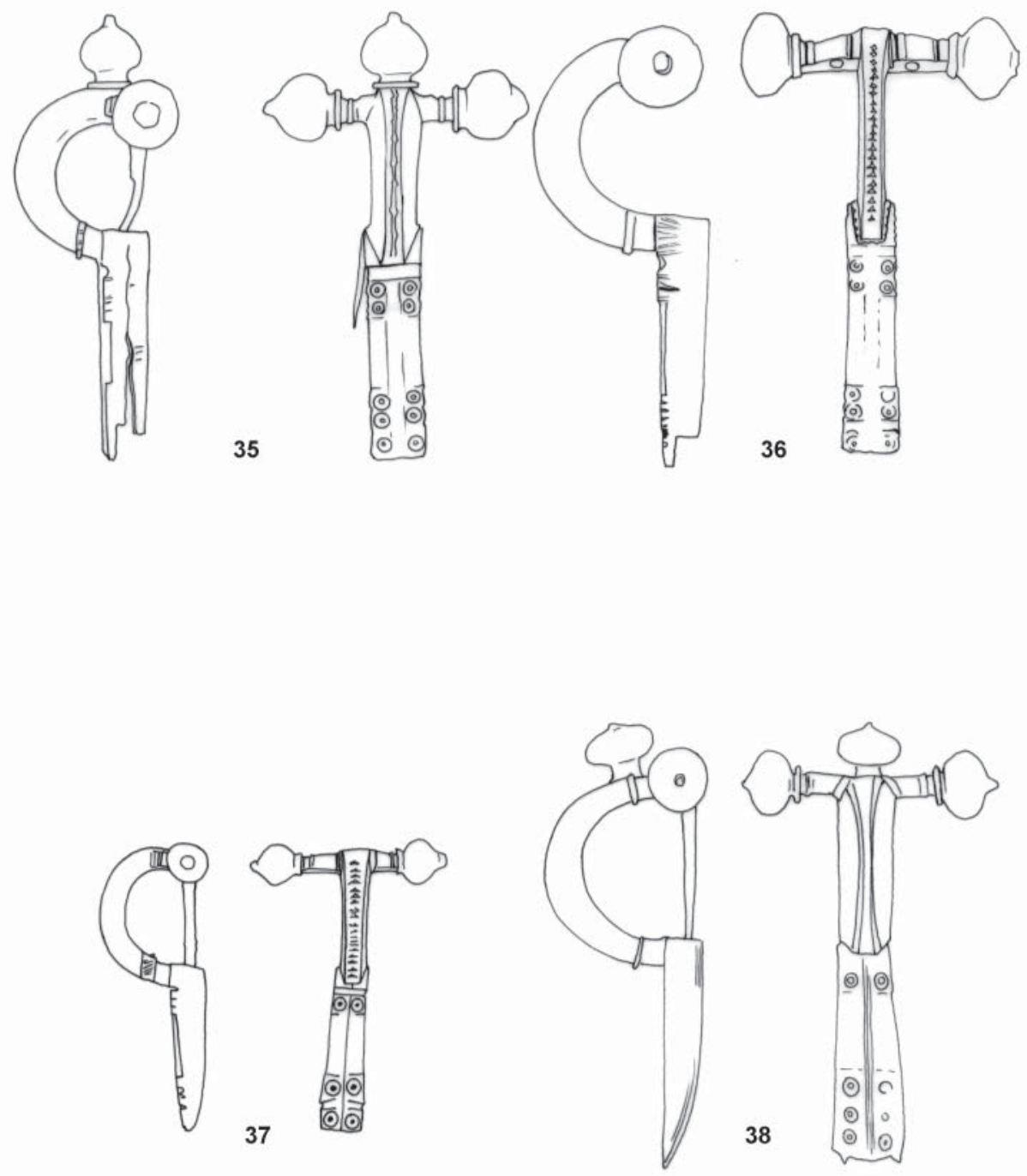

R 2:3 
T. IX
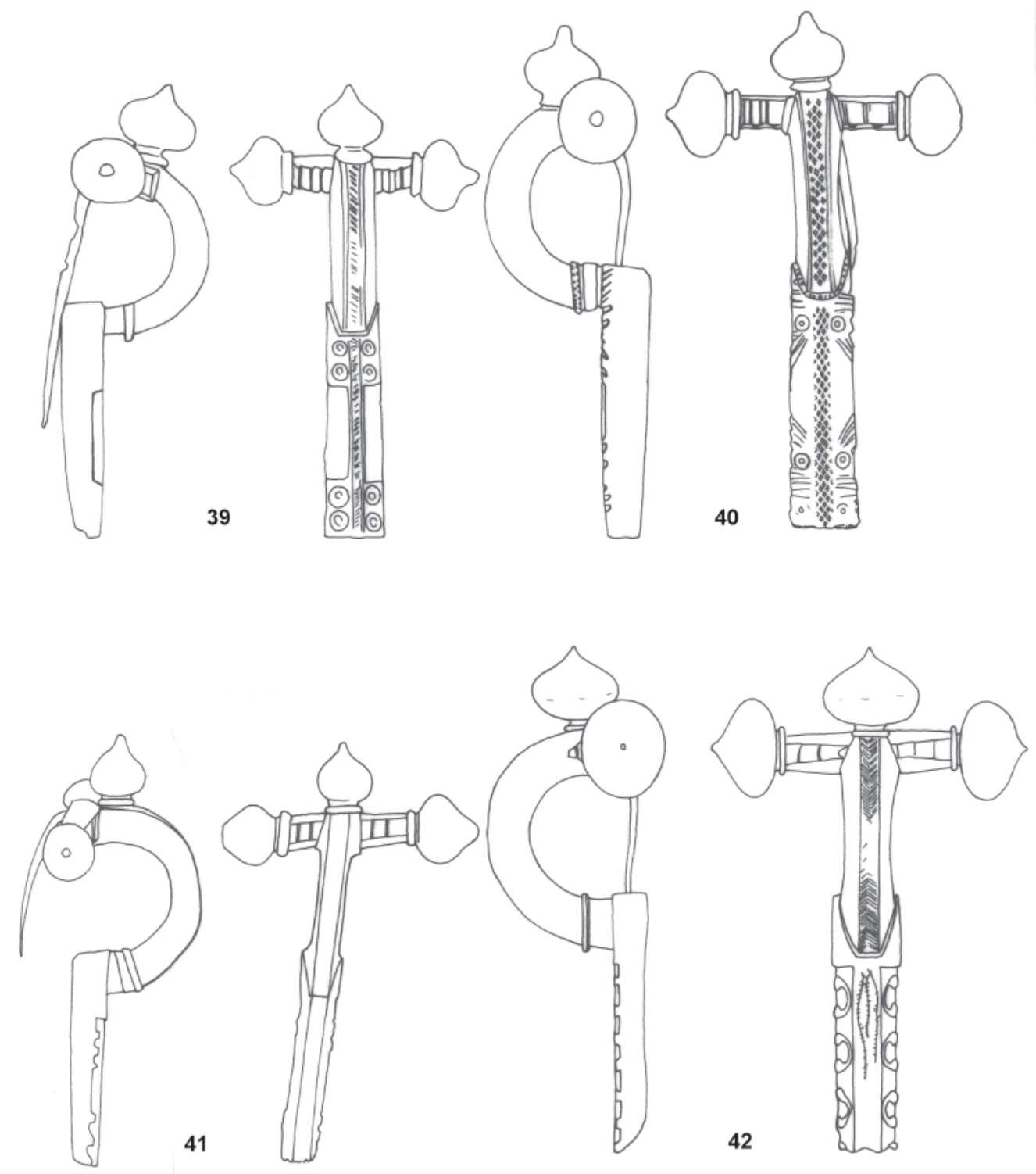

R 2:3 
T. X
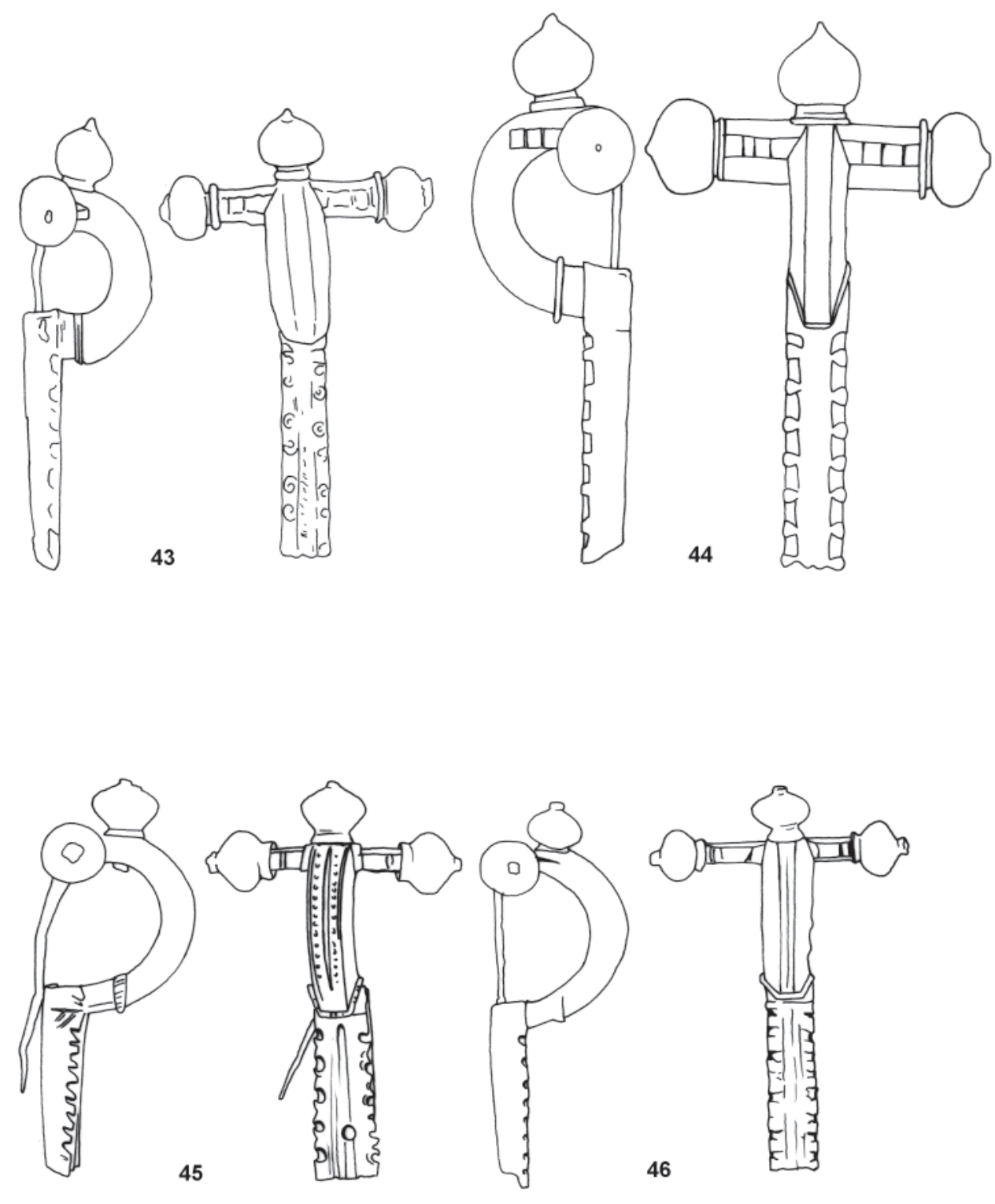

R 2:3 
T. XI
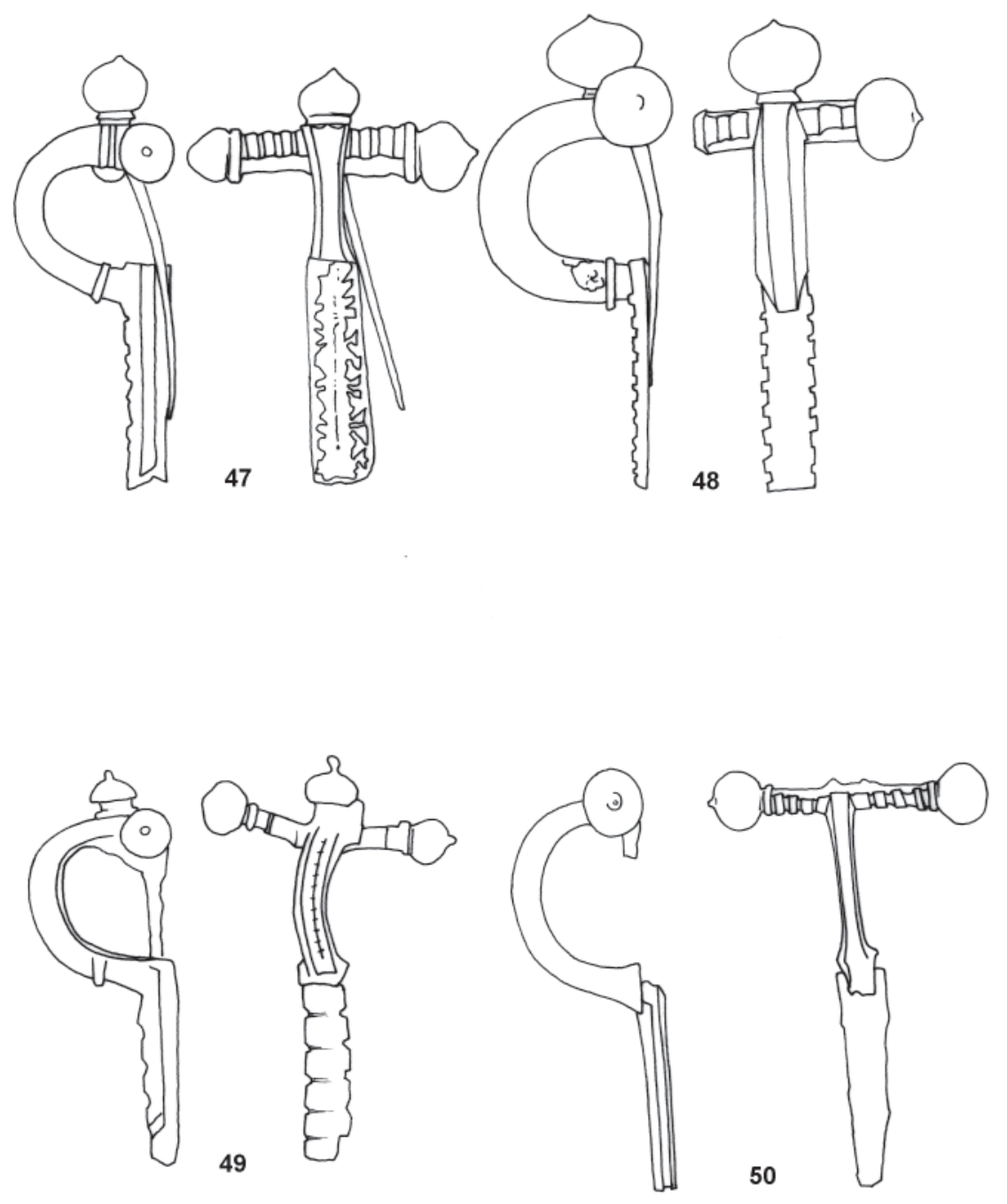

R 2:3 
T. XII
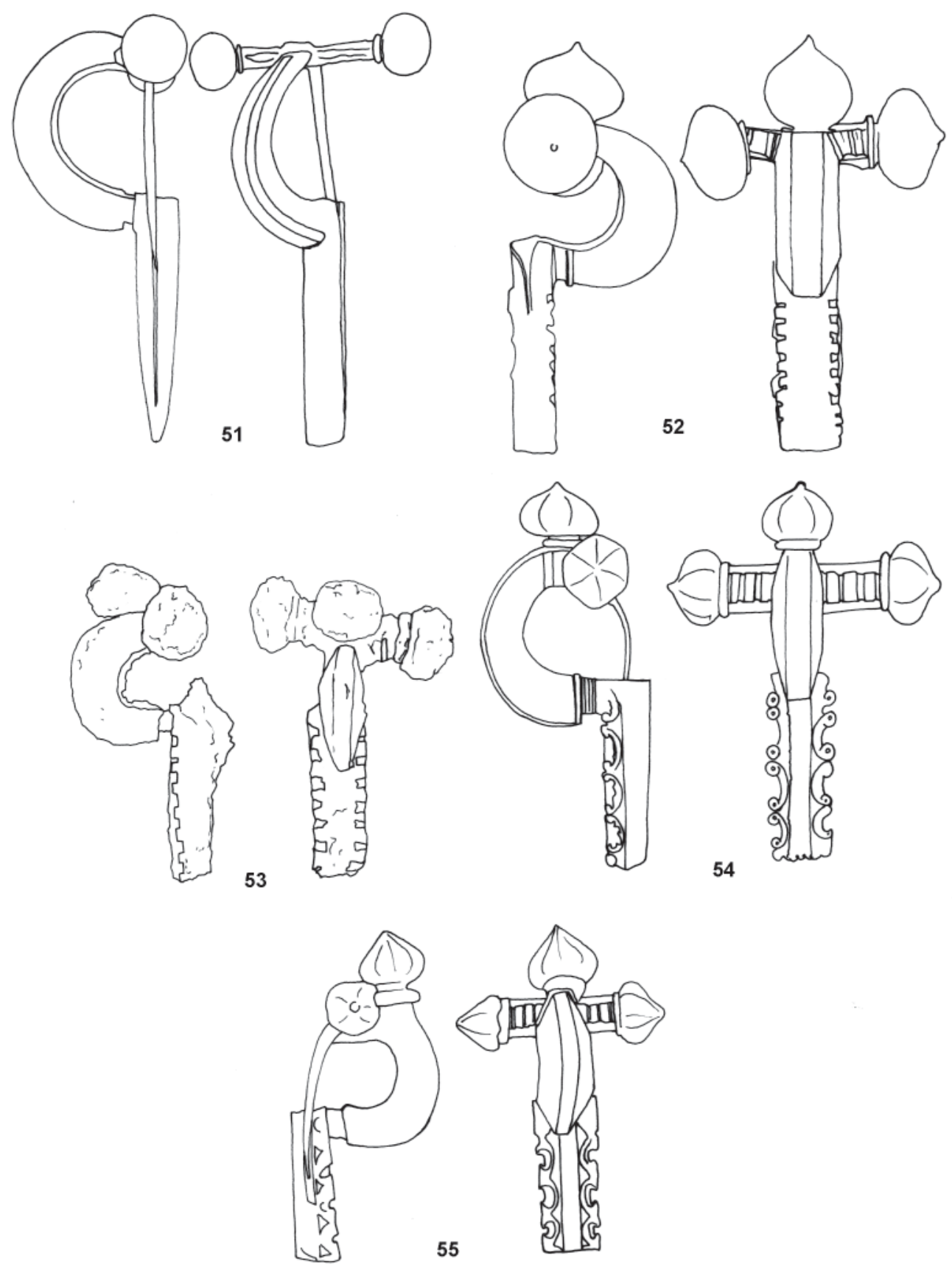

R 2:3 